\section{Ks. Dariusz Iwański}

Uniwersytet Mikołaja Kopernika, Toruń

e-mail: nagid@nagid.pl

DOI: http://dx.doi.org/10.12775/BPTh.2015.001

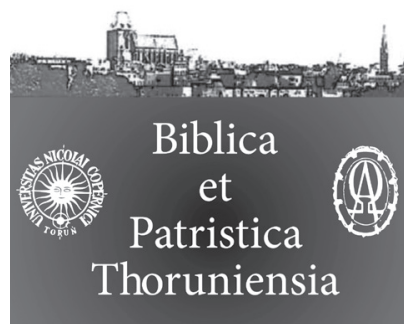

8 (2015) 1 ISSN 1689-5150

\title{
Motyw drzewa życia w Księdze Przysłów
}

\section{The Tree of life motif in the Book of Proverbs}

\begin{abstract}
Streszczenie. Motyw drzewa życia jest bardzo prominentny w tekstach mądrościowych całego Bliskiego Wschodu. Nic więc dziwnego, że znalazł swe zastosowanie także w biblijnej literaturze sapiencjalnej. Jego występowanie jest jednak ograniczone jedynie do Księgi Przysłów. Co więcej, występuje on tam zaledwie cztery razy: 3,18; 11,30; 13,12; 15,4 . W każdym z tych przypadków autor/autorzy posługuje się tym motywem do wyświetlenia nieco innych aspektów mądrości. Artykuł jest krótką prezentacją tych właśnie niuansów znaczeniowych obecnych w wyżej wskazanych tekstach Księgi Przysłów.
\end{abstract}

Abstract. The tree of life motif is very prominent in wisdom texts from the Ancient
Near East. No wonder than that it is also echoed in the biblical wisdom literature. How-
ever, it is only found in the Book of Proverbs. Yet, it occurs there four times only: 3,18 ;
11,30; 13,$12 ; 15,4$. In each case it becomes a vehicle for highlighting different shades
of meaning of Wisdom. The article is a short presentation of the above mentioned texts.

Słowa klucze: Mądrość; Księga Przysłów; Drzewo życia.

Keywords: Wisdom; the Book of Proverbs; the Tree of life.

$\mathrm{W}$ ikonografii chrześcijańskiej nierzadkie jest przedstawianie krzyża Chrystusa jako drzewa $\dot{z} y c i a^{1}$. Chodzi oczywiście o pośrednie odniesie-

1 Z pewnością w wielu wypadkach inspiracją dla takiego ujęcia był zapis znajdujący się w średniowiecznym dziele Jakuba de Voraigne zwanym Złotą legenda. Według niego, krzyż został wykonany z drewna pochodzącego z pnia drzewa, które wyrosło z pestki owocu zerwanego z rajskiego drzewa życia (por. np. G. Ferguson, Signs and Symbols in Christian Art, s. 50.99; M. Jacniacka, J. Szlaga, Drzewo Życia, s. 254; B.C. Lane, The tree as a giver of life, s. 16. Z drugiej jednak strony, D. Forstner, Świat symboliki chrześcijańskiej, s. 154-156, zauważa także, że motyw drzewa życia, jako symbol krzyża Chrystusa i ołtarza „który stoi w środku 'raju' Kościoła” jest częsty w pismach Ojców Kościoła, a pierwsze przykłady wykorzystania tego motywu w ikonografii chrześcijańskiej dają się zaobserwować już w malarstwie katakumbowym. 
nie do drzewa, które - według Księgi Rodzaju - znajdowało się w środku Ogrodu Eden (por. 2,9; 3,22-24) ${ }^{2}$. Motyw drzewa życia powraca w ostatniej księdze Biblii chrześcijańskiej - w Apokalipsie św. Jana (2,7; 22,2 [bis].14.19), gdzie jest mowa o tym, że przywilej spożywania owoców z tego wyjątkowego drzewa stanie się nagrodą dla zwycięskich chrześcijan. Trzeba to rozumieć jako metaforę nawiązującą do pierwotnego ładu stworzenia zakłóconego przez grzech, który Bóg ostatecznie przywróci na końcu czasów ${ }^{3}$. W ten sposób, symbolicznie, motyw drzewa życia znajduje się na początku i na końcu Biblii.

Wydaje się, że tak bogaty w treść motyw, jakim jest drzewo życia powinien być dość częsty w Piśmie św. Tymczasem obok wspomnianych wzmianek z Księgi Rodzaju i Apokalipsy św. Jana, występuje on jeszcze tylko w Księdze Przysłów: 3,$18 ; 11,30 ; 13,12 ; 15,4$. Warto przeanalizować te cztery teksty, aby zobaczyć, w jaki sposób mędrcy Izraela wykorzystali ten motyw ${ }^{4}$.

\section{Mądrość - w poszukiwaniu kosmicznego porządku}

Zanim przystąpimy do omówienia powyższych fragmentów, warto odnieść się w kilku słowach do biblijnej literatury mądrościowej, której Księga Przysłów jest częścią. Jak sama nazwa wskazuje mądrość jest w centrum refleksji tej lite-

2 G. von Rad, Genesis, s. 78, zauważa, że wzmianka o drzewie życia, pojawia się w Księdze Rodzaju najpierw wtedy, kiedy Bóg umieszcza człowieka w Ogrodzie (Rdz 2,9), a potem wówczas, kiedy go zeń wypędza ( $\mathrm{Rdz} 3,22-24)$. Po raz pierwszy czytamy o drzewie życia w Rdz 2,9 - gdzie występuje ono w środku ogrodu Eden obok drzewa poznania dobra i zła oraz wielu innych drzew rodzących smaczne owoce. Następnie, pojawia się ono dopiero w Rdz 3,22-24 obok drzewa poznania dobra i zła, które jest w centrum narracji. Wielu autorów chciało $\mathrm{w}$ tym widzieć ślady jakichś dwóch istniejących wcześniej niezależnie opowiadań, które ostatecznie zostały złączone w jedno dzięki czyjejś pracy redakcyjnej. P. Watson, The Tree of Life, s. 235.237, uważa jednak że jest to zbytnie uproszczenie. Wystarczy czytać Rdz 2,9 jako konkluzję dla wierszy Rdz 2,4b-8, które właściwie w całości dedykowane są tematowi życia. Człowiek staje się tam istotą żyjącą uformowaną przez Boga z prochu ziemi, w którą tchnął On swoje własne tchnienie życia. Stąd ostatecznym źródłem życia dla człowieka jest Bóg. Można by więc powiedzieć, że Rdz 2,4-9 tętni życiem. Bóg stwarza człowieka, napełnia go życiem i umieszcza w idealnym środowisku - w pięknym ogrodzie. Człowiek jednak nie będzie chciał żyć w takim miejscu na zasadach zaproponowanych przez Boga. Zdobędzie wiedzę, ale równocześnie utraci życie.

3 Por. D.E. Aune, Revelation 1-5, s. 151-152; H.N. Wallace, The Tree of Knowledge, s. 659; E.A. Speiser, Genesis, s. 20.

4 W poniższych rozważaniach pominięty zostanie wątek ewentualnych pozabiblijnych odniesień dla motywu drzewa życia, jako motywu znanego w starożytnej literaturze Bliskiego Wschodu. 
ratury. Mądrość rozumiana jest tu jako ars vivendi, czyli sztuka życia. Z drugiej strony mądrość sama w sobie jest życiem i życie zapewnia. Jest ona wreszcie częścią kosmicznego porządku, który Bóg ustanowił we wszechświecie, stwarzając go. Człowiek, który chciałby nabyć mądrości, winien się przede wszystkim odznaczać bojaźnią Pańską, a więc postawą głębokiego szacunku wobec Boga - Stwórcy wszechświata ${ }^{5}$. Ustanowiony przez niego ład obejmuje zasady i prawa rządzące światem, ale też i życiem poszczególnych ludzi. Poszukiwanie mądrości polega na poszukiwaniu i odkrywaniu tych zasad i praw, a następnie odzwierciedlaniu ich w swoim myśleniu i postępowaniu. Tak czyniąc, człowiek może liczyć na nagrodę, która oczekuje poszukujących mądrości. To jest z kolei trzeci najważniejszy filar światopoglądu mędrców - odpłata, czyli retrybucja. Nagrodą, o którą chodzi, jest po prostu życie, przy czym rozumie się je w sensie dostatniej, szczęśliwej i długiej egzystencji na tym świecie $e^{6}$.

Mędrcy Starego Testamentu ze wszech miar starali się ukazać mądrość, jako wartość, o którą należy zabiegać. Posługiwali się ciekawymi metaforami, aby dać czytelnikowi poczucie korzyści z posiadania mądrości. Jedną z nich było właśnie drzewo życia $(3: 18 ; 11: 30 ; 13: 12 ; 15: 4)^{7}$.

\section{Drzewo życia w Księdze Przysłów}

Jak już wspomniano na początku, motyw drzewa życia w Księdze Przysłów nawiązuje oczywiście do drzewa życia znanego z Księgi Rodzaju. Trudno się jednak oprzeć wrażeniu, że autor traktuje ten obraz z dużą swobodą. Po pierwsze, jest on tu pozbawiony wszelkich odniesień do nieśmiertelności ${ }^{8}$. Po drugie, autor nie trzyma się sztywno obrazu drzewa jako takiego. Drzewo można by z powodzeniem zastąpić terminem źródło, bez szkody dla wymowy całej metafory. Zasadniczy akcent pada oczywiście na drugą część wyrażenia - życie. O ile terminy drzewo i źródło stanowią pewien punkt odniesienia, o tyle są one niejako niezbędnym li tylko nośnikiem do „wyświetlenia” terminu życie. Nie ma w tym nic dziwnego zważywszy na fakt, iż życie to termin kluczowy dla literatury mądrościowej, o czym była mowa powyżej.

5 Por. L. Boström, The God of the Sages, s. 137; P.J. Nel, The Structure and Ethos, s. 111-112; A.W. Jenks, Theological Presuppositions, s. 43-75.

6 Por. D. Iwański, Speaking About, s. 51-60.

7 Por. D.K.K. Wong, The Tree of Life, s. 211.

8 Por. H.N. Wallace, The Tree of Knowledge, s. 658. 


\section{1. $\operatorname{Prz} 3,18$}

Drzewem życia ona [mądrość] dla tego, co do niej przylgnął, a kto się jej trzyma - szczęśliwy.

Omawiany tekst jest częścią krótkiego hymnu na cześć mądrości, który znajduje się w wierszach od 13 do 20 trzeciego rozdziału9 . Ten hymn akcentuje również szczęście tych, którzy mądrości szukali i ją znaleźli. Długie życie, bogactwo oraz prestiż $(3,16)$ to najważniejsze z dóbr, na które mogli liczyć. Wśród różnych obrazów ilustrujących korzyści płynące ze zdobywania mądrości pojawia się motyw drzewa życia $(3,18)$. Trudno nie zauważyć tu pewnej dwuznaczności. Otóż z jednej strony, mądrość jest ukazana jako ta, która stanowi źródło długiego i pomyślnego życia. $Z$ drugiej jednak ona jednocześnie podtrzymuje owo życie w takim wymiarze ${ }^{10}$. Aby jednak mogła przynieść takie rezultaty, człowiek musi mocno do niej przylgnąć i mieć ją niejako stale w objęciach $(3,18)$. Zaangażowanie człowieka jest niezbędne i jest ono przedstawione $\mathrm{w}$ naszym wierszu w dość śmiałych słowach, które w języku hebrajskim przywołują skojarzenia dotyczące alkowy.

Roland E. Murphy zwrócił uwagę na fakt, że cały prolog do Księgi Przysłów (rozdziały 1-9) przesycony jest terminologią dotyczącą życia małżeńskiego. Jego zdaniem, jest tu widoczne nawet swoiste zestawienie Mądrości i Erosa. Jako dowód wskazuje na przykład retorykę związaną z przedstawieniem Pani Mądrości, którą najpierw trzeba znaleźć ( $m \bar{a} s ̦ a \bar{a} 3,13 ; 8,17.35)$, tak jak się znajduje dobrą żonę $(18,22 ; 31,10)$. Na innym zaś miejscu, młodzieniec słyszy od mędrca, aby „nabywał mądrości”, aby ją „kochał” oraz „obejmował” ją (hābaq) (Prz 4,6-8). Jest to terminologia związana z miłością cielesną i małżeństwem ${ }^{11}$.

Ciekawe, że Murphy nie zauważył - bądź po prostu nie uznał za stosowne odnotować - tekstu Prz 3,18, który też nasycony jest słownictwem sugerującym bliską (czyt. intymną) zażyłość z kobietą. Chodzi najpierw o czasownik hạazaq w konigacji Hifil $(3,13 a)$. Podstawowe znaczenie tego czasownika to być lub stać się silnym, mocnym. W koniugacji Piel i Hifil termin ten nabiera znaczenia umacniać, czynić mocnym. Czasem jednak w Hifil zachodzi semantyczne przejście od znaczenia umacniać do chwytać, mocno trzymać12. Komentatorzy w większości oddają interesujący nas fragment w duchu tego ostatniego zna-

9 Por. B.K. Waltke, The Book of Proverbs, s. 256. Zob. także R.N. Whybray, The Book of Proverbs, s. 26.

10 Por. R. Marcus, The Tree of Life, s. 117.

11 Por. R.E. Murphy, Wisdom and Eros, s. 601-602.

12 Por. F. Hesse, קָָָ chāzaq, s. 302.304. 
czenia. Jednocześnie dokonują pewnej subtelnej modyfikacji, tłumacząc całość wyrażenia w Prz 3,13a jako ten, który strzeże bądź ten, który mocno przylgnął do. W takim sensie omawiany czasownik pojawia się na przykład w Prz 7,13, gdzie mowa o kobiecie rozpustnej, która uwodzi młodzieńca. Ona właśnie chwyta młodzieńca w objęcia i trzyma w intymnym uścisku.

Takie ujęcie jest jak najbardziej zgodne $\mathrm{z}$ wymową rzeczonego czasownika. Wydaje się jednak, że w naszym tekście pobrzmiewać może jeszcze coś więcej, a mianowicie niuans związany z relacją małżeńską. Ściślej mówiąc chodzi tu o mężczyznę, który w relacji do swej żony jest widziany jako ten, który ją umacnia lub ma nad niq władzę. Przykład takiego użycia czasownika hāzaq w Hifil można znaleźć w Dn 11,6 ${ }^{13}$. Gdyby uznać, że i w Prz 3,13a autor zamierzył również podobne znaczenie dla omawianego czasownika, to mielibyśmy przykład dość niezwykłego nagromadzenia treści w jednym wyrażeniu. Wówczas, obok motywu mocnego przylgnięcia do, byłby tu również zamierzony niuans ścisłej bliskości i zażyłości, jaka właściwa jest relacji małżeńskiej ${ }^{14}$. Sądzę, że należy uznać, że taka była właśnie intencja autora, który w ten sposób, grając na obrazach opisujących intymność życia małżeńskiego, wyraził potrzebę bliskości człowieka w stosunku do mądrości.

Drugi czasownik (tāmak) w Prz 3,18b należy rozpatrywać w kategoriach paralelizmu synonimicznego. Innymi słowy, chodzi tu o termin będący synonimem pierwszego czasownika. Występuje on w tekście w koniugacji Qal, a jego podstawowe znaczenie słownikowe to chwytać, uchwycić się, trzymać się (być pochwyconym Nifal). Mimo iż nie ma w Biblii przykładów występowania tego czasownika w kontekście intymnej zażyłości z kobietą, wydaje się, że kontekst jest wystarczającym argumentem za tym, aby tak właśnie interpretować go w Prz 3,18.

N. Habel zwraca uwagę na jeszcze jeden aspekt, który jest prawdopodobnie zawarty w obecnej tu metaforze drzewa życia. Według niego podstawową implikacją w Prz 3,13-20 jest ta, że mądrość nie przestaje dostarczać porządkujących principiów, które rządzą kosmosem. W jej określeniu, jako drzewo życia $(3,18)$ może być zawarty pierwotny charakter mądrości. W Rdz 3,24 czytamy o tym, że Cherubini zostają wyznaczeni do tego, aby strzegli drogi (derek $)$ do drzewa życia, które jest umieszczone w ogrodzie Eden, w miejscu pierwotnej szczęśliwości. Z kolei w Prz 3,17 miłe drogi i ścieżki prowadzą do drzewa ży-

13 Por. J.E. Goldingay, Daniel, s. 277. Według L. Koehler - Baumgartner, Lexicon in Veteris Testamenti Libros, „חז", s. 287, jest to termin techniczny na oznaczenie żenienia się.

14 Co ciekawe, w swoim późniejszym komentarzu do Księgi Przysłów, R.E. Murphy, Proverbs, s. 22, wyraźnie zauważa, że omawiany werset odzwierciedla erotyczny ton, w jakim Pani Mądrość jest opisana w tych rozdziałach. 
cia każdego, kto nimi idzie, aby ostatecznie wziąć w objęcia mądrość. Habel konkluduje zatem, twierdząc, że takie odwołanie się do obrazu drzewa życia z ogrodu Eden ma jeszcze bardziej wyeksponować mądrość jako tę która jest elementem pierwotnego kosmicznego porządku ustanowionego przez Boga ${ }^{15}$.

\section{2. $\operatorname{Prz} 11,30$}

Owocem sprawiedliwego drzewo życia, zaś sięgający po życie jest mądry.

Należałoby najpierw zauważyć, że Prz 11,30 znajduje się w końcowym fragmencie jedenastego rozdziału Księgi Przysłów. Zdaniem Bruce K. Waltke wiersz ten stanowi część większego bloku, który opatruje on tytułem: „Nieunikniona strata lub zysk" (Prz 11,28-31). W odniesieniu do Prz 11,30 Waltke twierdzi najpierw, że następuje tu dalsze rozwinięcie obrazu o drzewie rodzącym owoc znajdującym się w Prz 11,28b, a więc na początku wspomnianego bloku $^{16}$. Roland E. Murphy zauważył, że słowo „prawy” wiąże wiersze 30 i 31, natomiast termin „mądry” łączy wiersze 29 i 3017. Perykopa Prz 11,28-31 jest zatem „utkana” z wielkim kunsztem i bardzo bogata w treść.

Nie jest to jednak tekst wolny od trudności. Główne problemy nastręcza interpretacja interesującego nas wiersza $(11,30)$. Ściślej mówiąc, chodzi o wyrażenie znajdujące się w drugim członie zdania: lōqēah $n^{e} p \bar{a} s \hat{s} o ̂$. Na przełomie wieków wśród komentatorów zarysowały się dwie główne interpretacje omawianego wyrażenia. Pierwsza, najbardziej popularna także i dzisiaj, jest następująca: ten, który zdobywa dusze (he who wins souls) ${ }^{18}$. Inna, bardzo rozpowszechniona, to ta, która widzi tu hebrajski idiom wziać $\dot{z} y c i e$, czyli zabić. Niestety, oba te tłumaczenia nie pasują do kontekstu, zatem należy je odrzucić ${ }^{19}$.

W niniejszym opracowaniu przyjąłem interpretację L.M. Fieldsa, którą uważam za najbardziej spójną i przekonującą. Proponuje on, aby odwołać się do podstawowego znaczenia występującego tu czasownika lāqah, który oznacza brać, wziaćc. Chodzi tu jednak o branie owoców, a ściślej mówiąc o ich zry-

15 Por. N. Habel, The Symbolism of Wisdom, s. 150-152.

16 Por. B.K. Waltke, The Book of Proverbs, s. 513.

17 Por. R.E. Murphy, “Catchwords”, s. 242.

18 Biblia Tysiąclecia4: „człowiek mądry ludzi zjednywa”; Biblia Poznańska: „mądry zdobywa dusze”; Biblia - Edycja św. Pawła: „mądry jest ten, kto kształtuje dusze”.

19 L.M. Fields, Proverbs 11:30, s. 531-532, wymienia jeszcze inne popularne interpretacje, a mianowicie: „rozumieć”, „przyciągać/wabić” i wreszcie „zbawić/ocalić”. 
wanie/zbieranie. W podobnym kontekście czasownik ten występuje w opowiadaniu o zerwaniu przez Ewę owocu $\mathrm{z}$ drzewa poznania dobra $i$ zła $(\operatorname{Rdz} 3,6)$.

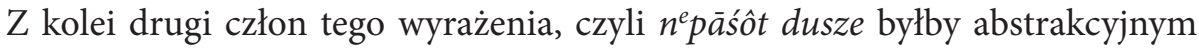
terminem oznaczającym życie (błogosławione i dostatnie $\dot{z} y c i e$ ). Zatem tłumaczenie całości omawianego wiersza wyglądałoby następująco: Owocem prawego jest drzewo życia, a ten, który siega po to dobre życie, jest madry (The fruit of the righteous is a tree of life, and the one who plucks that good life is wise). Logika tego stwierdzenia jest bardzo prosta: ten, kto wiedzie prawe życie, będzie rodził owoc, czyli życie, które mimo iż poza Ogrodem Eden, jest widziane z ziemskiej perspektywy jako równie atrakcyjne ${ }^{20}$.

Ponadto warto zauważyć, że przykład życia człowieka sprawiedliwego, a także jakość życia, o której tu mowa, mają siłę oddziaływania na innych. Sprawiedliwy, w sposób oczywisty i zgodny z naturą pouczeń mądrościowych, odnosi korzyść ze swego dobrego postępowania. Prz 11,30b odwraca niejako perspektywę, mówiąc, że mądrym jest ten, kto sięga po takie życie - czyli chce iść drogą prawości.

Trudno nie zgodzić się z R. N. Whybrayem, który uważa nazwanie owocu „drzewem” za dość niechlujną metaforę (careless metaphore). Niemniej jednak jej znaczenie jest jasne: prawość otrzymuje jako nagrodę „życie” - to znaczy wszelakiego rodzaju szczęście ${ }^{21}$. Wymowę naszego wiersza można zatem ująć $\mathrm{w}$ ten sposób, że drzewo życia jest równoznaczne z owocem, który jest z kolei synonimem nagrody, jaką sprawiedliwy odbiera od Boga za swą decyzję kroczenia drogą sprawiedliwości. Prz 11,30b stwierdza, że człowiek, który wybiera ten sam prawy i błogosławiony styl życia, jest mądry. Oczywiście zarówno owoc, jak i drzewo życia wskazują na życie, będące ideałem w literaturze mądrościowej - a więc życie w najwyższej jakości, ale w granicach doczesności.

\section{3. $\operatorname{Prz} 13,12$}

Nadzieja długo nieziszczona czyni serce chorym, a drzewem życia jest spełniające się pragnienie.

Interesujący nas werset rozpoczyna blok Prz 13,12-19, którego motywem przewodnim jest $\mathrm{z}$ jednej strony spełnienie, a $\mathrm{z}$ drugiej frustracja. Na pierwsze $\mathrm{z}$ nich mogą liczyć mądrzy, podczas gdy drugie przypadnie w udziale głupcom. Właśnie te dwie kategorie ludzi są tu przedmiotem stosownej refleksji. Oczywiście w tle pobrzmiewają nauki, przestrogi i napomnienia mędrców, którzy wskazu-

Por. L.M. Fields, Proverbs 11:30, s. 531-534.

21

Por. R.N. Whybray, The Book of Proverbs, s. 70. 
ją właściwą drogę. Mieć spełnionym własne pragnienie jest już samo w sobie drzewem życia. Jednak, aby móc się cieszyć tym owocem trzeba najpierw obudzić w sobie pragnienie życiodajnej nauki mędrców ${ }^{22}$.

O ile Prz 13,7-11 porusza temat bogactwa, które zapewnić może stabilizację, o tyle Prz 13,12 jakby odchodzi od tego wątku i skupia się na pragnieniu i jego spełnieniu ${ }^{23}$. Stopniowe gromadzenie dóbr może ostatecznie prowadzić do bogactwa, ale ponieważ jest to długi proces, spełnienie ludzkich oczekiwań może się wydawać bardzo odroczone w czasie ${ }^{24}$. To z kolei skutkuje określonym stanem ducha człowieka. Niektórzy komentatorzy chcą widzieć w omawianym tekście psychologiczną obserwację, dotyczącą ludzkiej natury ${ }^{25}$. Chodzi mianowicie o to, iż przewlekłe oczekiwanie na ziszczenie się pragnień może ostatecznie doprowadzić do upadku morale, zniechęcenia i frustracji.

Nadzieja (tôhelet), o której tu mowa, to oczywiście oczekiwanie na coś, czy pragnienie czegoś. B. K. Waltke uważa, że chodzi tu o przejście od niedoli do powodzenia. Hebrajski termin $m^{e} m u \check{s} \check{s} a \bar{k} a \bar{h}$ oznacza niekończące się wydłużenie w czasie. Tak źle rokująca zewnętrznie sytuacja czyni ludzkie serce zgorzkniałym, ,infekując” ostatecznie całego człowieka w jego fizycznym, psychicznym i duchowym wymiarze. Użyty tu czasownik hāāāh w formie participium koniugacji Hifil oznacza dosłownie - uczynić chorym, sprowadzić chorobę. W grę mogą wchodzić różne dolegliwości - od fizycznej i umysłowej niemocy, poprzez choroby dotykające różnych części ciała, aż po różnego rodzaju rany i obrażenia. W naszym wypadku chodzi jednak najbardziej o to, że człowiek sfrustrowany traci motywację do dalszego działania. $Z$ drugiej strony pokazany jest przykład człowieka spełnionego. Z kontekstu wynika, że chodzi tu o człowieka sprawiedliwego, którego spełnione pragnienia są jak drzewo życia, bądź żeby być bardziej dokładnym - jak spożywanie owoców z tegoż drzewa. Metafora drzewa życia w Prz 13,12a staje się antytezą dla choroby, o której mowa w Prz $13,12 \mathrm{a}^{26}$.

22 Por. B.K. Waltke, The Book of Proverbs, s. 562.

23 Por. O. Plöger, Sprüche Salomos, s. 160.

24 Por. R.E. Murphy, Proverbs, s. 97.

25 Por. O. Plöger, Sprüche Salomos, s. 160; R.E. Murphy, Proverbs, s. 95.97; M.V. Fox, Proverbs 10-31, s. 566.

26 Por. B.K. Waltke, The Book of Proverbs, s. 562-563. Por. L.M. Fields, Proverbs 11:30, s. 525 . 


\subsection{Prz 15,4}

Pokrzepiająca mowa drzewem życia,

Przewrotność w niej (mowie) złamaniem ducha.

Struktura rozdziału 15 Księgi Przysłów jest wciąż przedmiotem dyskusji. Niezależnie od podejścia do tego zagadnienia łatwo jednak zaobserwować, że stosunkowo dużo miejsca zajmuje w nim tematyka języka i mówienia (por. Prz 15,1 2.4.7.23.26.28 ${ }^{27}$. Także interesujący nas wiersz odnosi się do tej tematyki eksponując potęgę słowa, które ma moc leczyć lub ranić.

Aby dobrze zrozumieć wymowę tego przysłowia, trzeba najpierw ustalić znaczenie pierwszej jego części, w której kluczową metaforą jest drzewo życia. Prz 15,4 rozpoczyna się od wyrażenia marpē läšôn. Ostateczne tłumaczenie zależy od identyfikacji rdzenia znaczeniowego, z jakiego wywodzi się pierwszy człon wyrażenia. L. M. Fields zauważa, że w interpretacji tego wiersza zarysowały się dotąd trzy rozwiązania. Niektórzy egzegeci uznali, że wyraz pochodzi od czasownika rāfáa, czyli leczyć, uzdrawiać. Inni chcieli w nim widzieć pochodną czasownika rāfāh, a więc rozluźnić, zapadać się, łagodzić. Byli wreszcie i tacy, którzy traktowali omawiany termin, jako rzeczownik odczasownikowy (wywodzący się z rāfâa) o znaczeniu spokój, cisza ${ }^{28}$.

W niniejszym opracowaniu przyjąłem interpretację M. V. Foxa, który twierdzi, że chodzi tu o rzeczownik oznaczający lekarstwo (Prz 6,15), bądź balsam leczniczy (Prz 4,22; 12,18; Jr 14,19). W całości nasze wyrażenie będzie dosłownie oznaczać balsam języka, co stanowi oczywiście przenośnię odnoszącą się do kojącej, łagodnej i pokrzepiającej mowy ludzkiej ${ }^{29}$. Taka mowa, kontynuuje dalej nasze przysłowie, jest drzewem życia. Z kontekstu wiemy, że taka mowa charakteryzuje człowieka prawego i mądrego. Wydaje się jednak, że chodzi tu o przymiot, który przynosi o wiele więcej dobra wspólnocie niż samemu człowiekowi, któremu jest właściwy. Jego beneficjentami są osoby trzecie ${ }^{30}$.

B. K. Waltke stwierdza nawet, że metafora drzewa życia w tym kontekście ma w ludziach wyostrzyć pragnienie przywrócenia realiów raju w obecnym zepsutym świecie poprzez uzdrawiającą mowę, która daje życie wieczne tym, którzy się nią „karmią" ${ }^{1}$. Oczywiście w tym stwierdzeniu zawarta jest spora przesada zwłaszcza odnośnie do życia wiecznego, które jest raczej obcą mędr-

\footnotetext{
27 Por. R.E. Murphy, Proverbs, s. 111.

Por. L.M. Fields, Proverbs 11:30, s. 525-526 [przyp. 27]. 
com koncepcją. Niemniej jednak Waltke ma rację, że pobrzmiewa tu nostalgia za harmonią, która charakteryzowała świat w realiach raju. $Z$ drugiej strony jest tu również wyrażony wielki realizm odnośnie do siły słowa, które jest zdolne zapalać, bądź gasić ducha. To ostatnie jest wyrażone dobitnie w końcowej części wiersza - przewrotność języka skutkuje złamaniem ducha.

\section{Wnioski}

Przeanalizowane teksty z Księgi Przysłów, w których występuje motyw drzewa życia, w sposób oczywisty nawiązują do rajskiego drzewa, które - zgodnie z opisem Księgi Rodzaju - stało w środku Ogrodu Eden. Analizowane teksty ukazały wyraźnie, że Księga Przysłów nie chce w tej materii trzymać się sztywno tego motywu, to znaczy tego, jak występuje on w Księdze Rodzaju. Pierwszym sygnałem, który na to wskazuje, jest różnica w hebrajskim zapisie wyrażenia, o którym mowa. Otóż w złożeniu drzewo życia występującym w Księdze Rodzaju słowo $\dot{z} y c i e$ jest zawsze poprzedzone rodzajnikiem określonym, podczas gdy w przykładach z Księgi Przysłów brak tego rodzajnika.

Swoboda w posługiwaniu się omawianym motywem jest również widoczna w tym, że wyraz drzewo może zostać zastąpiony wyrazem źródło i to właściwie bez zaciemnienia treści, jaką przekazuje. Faktycznie, wyrażenie źródło życia $m^{e}$ qôr hayyîm jest równie częste w Księdze Przysłów (por. Prz 10,11; 13,14; $14,27 ; 16,22)$. Oba te wyrażenia o tyle znajdują zastosowanie w Księdze Przysłów, o ile pomagają wybrzmieć tematowi życia. To ostatnie, jest oczywiście rozumiane w kategoriach mądrościowych, a więc dotyczących bardziej egzystencji na ziemi niż życia wiecznego w jakimś ziemskim raju (Rdz) lub wiecznego, eschatologicznego życia w niebiańskim raju (Ap) ${ }^{32}$.

$\mathrm{Z}$ drugiej strony jednak trudno byłoby utrzymać twierdzenie, że autor nie jest świadom innych odniesień zawartych w motywie drzewa życia. Otóż drzewo życia, jako element rajskiego krajobrazu, musi przywoływać na pamięć pierwotny kosmiczny porządek ustanowiony przez Stwórcę. Ten porządek jest jednym z podstawowych filarów, na których zasadza się światopogląd mędrców. Z pewnością więc wyrażenie drzewo życia, ze względu na tę podwójną symbolikę było szczególnie drogie mędrcom.

Ostatecznie więc można się pokusić o stwierdzenie, że w Księdze Przysłów drzewo życia jest wyrażeniem, które przeszło już pewną ewolucję znaczeniową w stosunku do swego pierwowzoru z Księgi Rodzaju i funkcjonowało w codziennym użyciu, jako synonim najbardziej pożądanych wartości i dóbr.

32 Por. L.M. Fields, Proverbs 11:30, s. 525. 
W tym sensie wykorzystanie omawianego motywu w literaturze i ikonografii chrześcijańskiej jako odnoszącego się do krzyża Chrystusa jest jak najbardziej spójne z jego użyciem w Księdze Przysłów. Kiedy św. Paweł powie, że dla niego największą chlubą jest „krzyż Chrystusa” (Ga 6,14; por. 1 Kor 1,17), to jednocześnie nie pozostawi żadnych wątpliwości odnośnie do tego, jaką wartość ma drzewo, przez które otrzymaliśmy życie. Jednocześnie jest jasne, że drzewo to staje się życiodajne dopiero, gdy jest rozpatrywane w aspekcie Jezusa, który na nim umarł. Ten właśnie obraz Jezusa Chrystusa ukrzyżowanego nie tylko stoi w centrum chrześcijańskiego przepowiadania, ale wyznacza również nowe kanony mądrości (por. 1 Kor 1,23-24).

\section{Bibliografia}

Aune D.E., Revelation 1-5 (WBC 52A; Dallas 1997).

Boström L., The God of the Sages. The Portrayal of God in the Book of Proverbs, Coniectanea biblica, Old Testament 29, Stockholm 1990.

Ferguson G., Signs and Symbols in Christian Art, New York 1954.

Fields L.M., Proverbs 11:30: Soul-Winning or Wise Living?, Journal of the Evangelical Theological Society 50 (2007), s. 517-535.

Forstner D., Świat symboliki chrześcijańskiej (tł. pol.), Warszawa 1990.

Fox M.V., Proverbs 10-31. A New Translation with Introduction and Commentary, The Anchor Bible 18B, New Haven-London 2009.

Goldingay J. E., Daniel, Word Biblical Commentary 30, Nashville 1989.

Habel N., The Symbolism of Wisdom in Proverbs 1-9, Interpretation 26 (1972), s. 131$-157$.

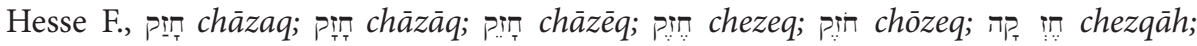
חד: chozqäh, w: Theological Dictionary of the Old Testament IV, s. 301-308.

Iwański D., Speaking About Biblical Wisdom, Collectanea Theologica 77 (2007) s. 51-60. Jacniacka M., Szlaga J., Drzewo Życia, w: Encyklopedia Katolicka, t. IV, s. 253-255.

Jenks A.W., Theological Presuppositions of Israel's Wisdom Literature, Horizons in Biblical Theology 7 (1985) s. 43-75.

Koehler L., Baumgartner W., prn, w: Lexicon in Veteris Testamenti Libros, s. 286-288.

Lane B.C., The tree as a giver of life: A Metaphor in Pastoral Care, The Journal of Pastoral Care XLV/1 (1991) s. 15-22.

Marcus R., The Tree of Life in Proverbs, Journal of Biblical Literature 62 (1943), s. 117-120 .

Murphy R.E., Wisdom and Eros in Proverbs 1-9, Catholic Biblical Quarterly 50 (1988) s. 600-603.

Murphy R.E., 'Catchwords' in Proverbs 10:1-22:13, w: Learning from the Sages: Selected Studies on the Book of Proverbs, R.B. Zuck (red.), Grand Rapids 1995, s. 241-248 . 
Murphy R.E., Proverbs, Word Biblical Commentary 22, Nashville 1998.

Nel P.J., The Structure and Ethos of the Wisdom Admonitions in Proverbs, Beihefte zur Zeitschrift für die Alttestamentliche Wissenschaft 158, Berlin-New York 1982.

Plöger O., Sprüche Salomos (Proverbia), Biblischer Kommentar: Altes Testament XVII/2-4, Neukirchen-Vluyn 1983.

Pokrifka J., Life, Imagery of, w: Dictionary of the Old Testament. Wisdom, Poetry \& Writings, T. Longman III, P. Enns (red.), Downers Grove-Nottingham 2008, s. $431-437$.

Rad von G. Genesis. A Commentary. Revised Edition, Old Testament Library, Philadelphia 1973.

Speiser E.A., Genesis, The Anchor Bible 1, Garden City-New York 1964.

Wallace H.N., The Tree of Knowledge and Tree of Life, w: The Anchor Bible Dictionary VI, Yale University Press, London 1992, s. 656-660.

Waltke B.K., The Book of Proverbs: Chapters 1-15, New International Commentary on the Old Testament, Grand Rapids-Cambridge 2004.

Watson P., The Tree of Life, Restoration Quarterly 23 (1980), s. 232-238.

Whybray R.N., The Book of Proverbs, The Cambridge Bible Commentary, Cambridge 1972.

Wong D.K.K., The Tree of Life in Revelation 2:7, Bibliotheca Sacra 155 (1998), s. $211-$ $-226$. 